\title{
Stem cell approaches for diabetes: towards beta cell replacement
}

\author{
Gordon C Weir*, Claudia Cavelti-Weder and Susan Bonner-Weir
}

\begin{abstract}
Stem cells hold great promise for pancreatic beta cell replacement therapy for diabetes. In type 1 diabetes, beta cells are mostly destroyed, and in type 2 diabetes beta cell numbers are reduced by $40 \%$ to $60 \%$. The proof-of-principle that cellular transplants of pancreatic islets, which contain insulin-secreting beta cells, can reverse the hyperglycemia of type 1 diabetes has been established, and there is now a need to find an adequate source of islet cells. Human embryonic stem cells can be directed to become fully developed beta cells and there is expectation that induced pluripotent stem (iPS) cells can be similarly directed. iPS cells can also be generated from patients with diabetes to allow studies of the genomics and pathogenesis of the disease. Some alternative approaches for replacing beta cells include finding ways to enhance the replication of existing beta cells, stimulating neogenesis (the formation of new islets in postnatal life), and reprogramming of pancreatic exocrine cells to insulin-producing cells. Stem-cellbased approaches could also be used for modulation of the immune system in type 1 diabetes, or to address the problems of obesity and insulin resistance in type 2 diabetes. Herein, we review recent advances in our understanding of diabetes and beta cell biology at the genomic level, and we discuss how stem-cell-based approaches might be used for replacing beta cells and for treating diabetes.
\end{abstract}

Keywords Beta cell, embryonic stem cell, islet, islet regeneration.
*Correspondence: gordon.weir@joslin.harvard.edu

Section on Islet Cell and Regenerative Biology, Research Division, Joslin Diabetes Center, One Joslin Place, Boston, MA 02215, USA, and the Department of Medicine, Harvard Medical School, 25 Shattuck Street, Boston, MA 02115, USA

\section{The problem of diabetes: prospects for stem-cell-based approaches}

The promise of stem-cell-derived therapies holds particularly high hopes for diabetes. The prevalence of both type 1 and type 2 diabetes continues to climb and their complications are devastating. In type 1 diabetes, the beta cells are decimated by autoimmunity and for unknown reasons the disease is being seen more often. Type 2 diabetes accounts for over $95 \%$ of diabetes cases worldwide and its increase is mainly caused by the encroachment of Western lifestyles of poor diet and lack of exercise, leading to insulin resistance and obesity. Advances in genomics and other fields have produced a dramatic generation of new knowledge that enhances our understanding of the pathogenesis of all forms of diabetes and provides exciting new avenues for treatment.

The potential of stem cell approaches for diabetes is particularly attractive because the development of both forms of diabetes is dependent upon deficiency of pancreatic beta cells, and the diabetic state can be reversed using beta cell replacement therapy. For type 1 diabetes this concept is supported by the success of pancreas and islet transplantation [1,2]. For type 2 diabetes, the potential of beta cell replacement is less well understood because so much focus has been on insulin resistance, which is certainly an important therapeutic target. However, most people with insulin resistance never progress to the diabetic state. Those who do progress to type 2 diabetes have reduced beta cell mass, which is typically $40 \%$ to $60 \%$ of normal, as determined by autopsy studies [3]. Moreover, normal glucose levels can be restored in type 2 diabetes using beta cell replacement in the form of pancreas transplantation [4]. The progression of complications to the eyes, kidneys and nerves can be largely halted by prevention of hyperglycemia [5]. Therefore, advances in stem cell biology have the potential to make beta cell restoration possible as an approach for both forms of diabetes.

There are also other ways in which stem cell biology might be helpful for diabetes. For example, there is great interest in mesenchymal stromal cells and the possibility that they could modulate autoimmunity or somehow promote islet cell regeneration [6]. Stem cell approaches 
might also be applied in a variety of other ways to modulate the immune system to prevent killing of beta cells. With regard to type 2 diabetes, work on stem cells might lead to innovative approaches to the problems of obesity and insulin resistance. In addition, stem cell science could be applied to treat diabetic complications such as atherosclerosis and microvascular disease. Equally as important, the prospect of obtaining induced pluripotent stem (iPS) cells from individuals with various forms of diabetes has recently opened up opportunities to study the individual cell types that are important in pathogenesis [7]. In this review, we discuss many of these opportunities and highlight how advances in genomics and other disciplines have advanced these endeavors.

\section{Understanding the genetics of diabetes through genomics}

\section{Type 1 diabetes}

This form of diabetes is caused by a complex combination of genetic and environmental factors [8]. Finding that only about $50 \%$ of identical twins are concordant for diabetes highlights the importance of the environment. The most important genetic contribution, which accounts for about $50 \%$ of the genetic influence, comes from the locus containing the HLA class II genes. The next most important locus is that of the insulin (INS) VNTR (variable number of tandem repeats), which is of considerable interest because insulin has been proposed as the key antigen initiating the process of autoimmunity [9]. Further advances in genetics, most notably highdensity genome-wide association studies (GWAS), have led to the identification of over 40 loci associated with type 1 diabetes [10]. All of these associations are weak but the influence of an individual gene is likely to be important in a particular family, probably even more so when combined with the effects of other genes. Loci of special interest also include genes encoding cytotoxic T-lymphocyte-associated protein 4 (CTLA4), protein tyrosine phosphatase-22 (PTPN22), and IL2 receptor alpha (IL2A).

\section{Type 2 diabetes}

This is far and away the most common form of diabetes. It has long been known to be strongly determined by genetics, as evidenced by numerous family studies, but finding the responsible genes has proved to be extremely difficult. Now GWAS have identified more than 40 loci associated with the disease [10]. The surprise to many was that most of these loci contained genes related to beta cell development and function, and relatively few were linked to insulin resistance and obesity. However, a central role for beta cell failure is now accepted to be an essential part in the pathogenesis of type 2 diabetes [11]. A problem is that the associations with type 2 diabetes
Table 1. Some forms of monogenic or maturity-onset diabetes of the young

\begin{tabular}{|c|c|c|}
\hline Type & Protein & Description \\
\hline MODY 1 & HNF4A & Loss-of-function mutations \\
\hline MODY 2 & Glucokinase & $\begin{array}{l}\text { Many forms, most often mild diabetes, } \\
\text { can cause hypoglycemia }\end{array}$ \\
\hline MODY 3 & HNF1A & Loss-of-function mutations \\
\hline MODY 4 & PDX1 & $\begin{array}{l}\text { Pancreas atrophy and beta cell } \\
\text { impairment }\end{array}$ \\
\hline MODY 5 & HNF1B & Pancreas atrophy and renal disease \\
\hline MODY 6 & NeuroD1 & $\begin{array}{l}\text { Transcription factor important for beta } \\
\text { cell development }\end{array}$ \\
\hline $\begin{array}{l}\text { Permanent } \\
\text { neonatal } \\
\text { diabetes }\end{array}$ & $\begin{array}{l}\text { KCNJ11, } \\
\text { ABCC8, } \\
\text { neurogenin } 3\end{array}$ & $\begin{array}{l}\text { Can be associated with hypoglycemia } \\
\text { or diabetes. Some forms can be treated } \\
\text { with sulfonylureas }\end{array}$ \\
\hline $\begin{array}{l}\text { Transient } \\
\text { neonatal } \\
\text { diabetes }\end{array}$ & $\mathrm{ABCC} 8$ & Some forms remit with time \\
\hline
\end{tabular}

ABCC8, ATP-binding cassette, sub-family C, member 8; HNF1A, hepatocyte nuclear factor 1 homeobox A; HNF1B, hepatocyte nuclear factor 1 homeobox $B ; H N F 4 A$, hepatocyte nuclear factor 4 alpha; KCNJ11, potassium channel J11; MODY, maturity-onset diabetes of the young; NeuroD1, neurogenic differentiation factor 1; PDX1, pancreatic duodenal homeobox.

are very weak for all of these implicated genes and loci, and even taken collectively they are thought to account for only about $10 \%$ of the genetic influence [10]. Therefore, at present they have limited value in predicting susceptibility [12].

\section{Monogenic diabetes}

Diabetes caused by a single gene mutation has also been called maturity-onset diabetes of the young (MODY) $[13,14]$. The best-described forms, all inherited as autosomal dominant genes, are described in Table 1, but new versions and variants of MODY continue to be identified. Almost all forms of MODY are attributable to mutations that result in deficient insulin release and are not associated with insulin resistance.

\section{Pancreatic beta cells: transcriptional networks, epigenetics and microRNAs}

Because of their central role in diabetes, it is important to appreciate the characteristics of pancreatic beta cells [15] (Box 1). Many studies have provided good descriptions of these well-characterized cells, but the important point is that beta cells should be able to store and secrete insulin in an extraordinarily efficient manner. To keep glucose levels in the normal range with meals and exercise, increases and decreases in insulin secretion must be rapid and precise.

Thanks to advances in embryology, genomics and other techniques there has been extraordinary progress in understanding how beta cells develop and function. Much is now known about how definitive endoderm is 


Box 1. Characteristics of pancreatic beta cells
Synthesize and store large amounts of insulin
(about 20 pg per cell)
Convert proinsulin to insulin and C-peptide with over
95\% efficiency
Equimolar secretion of insulin and C-peptide
Secrete insulin in response to glucose with a biphasic pattern
Rapid secretory responses; increase or shut-off in less than
3 minutes
Responses to a variety of agents: for example, incretins, amino
acids, catecholamines, acetylcholine and sulfonylureas
Unique transcription factor expression combination (Pdx1, MafA,
Nkx6.1, Nkx2.2, Pax6, NeuroD1)
Unique pattern of metabolic pathways (glucokinase as a glucose
sensor, minimal lactate dehydrogenase and gluconeogenesis;
active mitochondrial shuttles: malate-aspartate, glycerol
phosphate, pyruvate-malate and pyruvate-citrate)
MafA, Maf transcription factor A; NeuroD1, neurogenic
differentiation factor 1; Nkx2.2, Nk2 homeobox 2; Nkx6.1, Nk6
homeobox 1; Pax6, paired box 6; Pdx1, pancreatic duodenal
homeobox.

formed in embryos and how this progresses to formation of the gut-tube and then to development of the exocrine and endocrine pancreas, as has been reviewed recently [16]. The roles of various key transcription factors have been identified, and now their place in transcriptional networks is being defined. Almost 20 years ago, the pancreatic duodenal homeobox ( $\mathrm{Pdx} 1)$ was found to be essential for pancreas development [17], and now we can better appreciate its complex contributions. For example, it plays a key role in the expression of neurogenin 3 (Ngn3), which is essential for the formation of all islet cell types. To activate Ngn3, Pdx1 appears to act in concert with four other transcription factors, namely one cut homeobox 1 (Hnf6), SRY-box containing gene 9 (Sox9), Hnf1b and forkhead box A2 (Foxa2) [18]. Another key transcription factor is Rfx6, a member of the RFX (regulatory factor X-box binding) family, which functions downstream of Ngn3 and is essential for the formation of all islet cell types except pancreatic polypeptide-producing cells [19]. Currently, there is considerable focus on the final stages of beta cell maturation and the large Maf transcription factors are of particular interest. Immature beta cells produce MafB and as they mature they switch to MafA production, which appears to be important for optimal glucose-stimulated insulin secretion [20].

Advances in epigenetics and microRNA studies have now made our understanding of transcriptional control even more complicated. These fields are still young but are proving to be important. Regulation of gene expression is highly influenced by chromatin remodeling, either by modification of histones or by methylation of DNA. Histone modification can occur by acetylation, methylation, ubiquitylation, phosphorylation or sumoylation. Methylation of DNA occurs mostly at CpG sites with the conversion of cytosine to 5-methylcytosine. An important insight into the epigenetic control of insulin gene expression came from the observation in human islets that a surprisingly large region of about $80 \mathrm{~kb}$ around the insulin gene is very enriched with marks of histone acetylation and H3K4 dimethylation [21]. Because insulin is the most important product of beta cells, it is not surprising that control of its expression would require elaborate mechanisms. Another interesting finding is that repression of the gene aristaless-related homeobox $(A r x)$ caused by DNA methylation is critical for maintaining beta cell phenotype [22]. Continued production of Arx would result in a pancreatic alpha cell phenotype.

Next-generation sequencing approaches have also started to provide important insights. Chromatin immunoprecipitation and parallel sequencing (ChiP-seq) technology has been used to study histone marks in human islets [23]. That study focused on H3K4me1, H3K4me2 and H3K4me3, which are associated with transcription activation, and $\mathrm{H} 3 \mathrm{~K} 27 \mathrm{me} 3$, which is associated with gene repression. There were expected findings and surprises. As predicted, some genes with repressed expression were enriched in H3K27me3. These included NGN3, which is critical for the development of islet cells, and HOX genes, which are important for early development. As expected, PDX1 was highly expressed in beta cells and was associated with enrichment of H3kme1. Surprisingly, however, for both insulin and glucagon genes, there was a paucity of activation markers.

Important roles for microRNAs in diabetes are also now starting to be understood [24]. There has been particular interest in microRNA-375, which is highly expressed in beta cells, and when knocked out in mice leads to reduction in beta cell mass and diabetes [25]. In addition, it has recently been shown that a network of microRNAs has a strong influence on insulin expression in beta cells [26].

\section{Pancreatic beta cells in diabetes}

Beta cells undergo many complex changes during the progression of diabetes, and these are beyond the scope of this review. However, a gradual decline in beta cell mass is fundamental to the development of type 2 diabetes. Many mechanisms for the decline have been proposed, and these include endoplasmic reticulum stress, toxicity from amyloid formation and oxidative stress, but the problem remains poorly understood [11]. It is also important to point out that as beta cell mass falls during the progression of type 2 diabetes, glucose levels rise, and beta cells in this environment of hyperglycemia 
become dysfunctional with marked impairment of insulin secretion and phenotypic changes [27]. This malfunction is attributed to 'glucose toxicity' and is reversible [27].

\section{Successes and challenges for islet transplantation}

The first successful transplantation of islet cells into the liver in 1989 established the proof-of-principle for cell transplantation in diabetic patients [28], which has been helpful for focusing research efforts towards this challenging goal. We know from animal studies that islet cells can function well in a variety of transplant locations, including subcutaneous and omental sites. Although challenging, even the pancreas remains a possibility as a transplant site. Interestingly, transplanted islet cells can function well even without maintaining their normal islet structure and vascularity [29].

The major challenges facing this approach are finding an adequate supply of islet cells and preventing transplanted or regenerated cells from being killed by immune destruction from autoimmunity and/or transplant rejection. Currently, islet transplants are performed using islets isolated from organ donor pancreases, but this supply will never be close to sufficient. Various approaches that might lead to an adequate supply of beta cells for replacement therapy can be found in Box 2 .

\section{Embryonic and induced pluripotent stem cells}

It has already been shown that human embryonic stem cells (ESCs) can be directed to become fully mature beta cells. This feat was accomplished by Novocell, Inc. (now ViaCyte, Inc.) by exploiting what was known about embryonic development and progress made with mouse ESCs [30]. A stepwise approach was used to direct human ESCs towards islet cells, in which culture conditions were coupled with sequential addition of growth and differentiation factors that were able to drive ESC differentiation to definitive endoderm, gut-tube endoderm, pancreas and then islet cells. It was possible to generate cells in vitro that had characteristics of islet cells but were not fully mature. However, after immature precursor cells were transplanted into immunodeficient mice, maturation progressed to produce beta cells that were convincingly normal with regard to multiple characteristics. Importantly, these cells could make and store fully formed insulin, release insulin in response to a glucose stimulation, and could cure diabetes in mice. However, much further research is needed before this advance can be brought to clinical application. For example, there is concern that these populations of precursor cells might contain cells that will form teratomas. A current strategy involves transplanting cells within a planar macroencapsulation immunoprotective device that is transplanted under the skin [31]. In addition, investigators are working to obtain full maturation in

\section{Box 2. Possible sources of beta cells for replacement therapy \\ Preparation of cells for transplantation \\ (a) Embryonic or induced pluripotent stem cells \\ (b) Adult stem/progenitor cells (islet neogenesis from duct cells or other precursor cells in the pancreas, or from non-pancreatic precursor cells) \\ (c) Beta cell replication \\ (d) Genetic engineering (conditional expression of specific genes in beta cells, or generation of cells that resist immune destruction) \\ (e) Reprogramming (for example, acinar, liver, intestine, other) \\ (f) Xenotransplants (porcine fetal, neonatal or adult; or other species) \\ Regeneration of the endocrine pancreas in vivo \\ (a) Regeneration through stimulation of neogenesis, replication or reprogramming}

vitro. To find better ways to direct the development of ESCs into mature beta cells, there has been some success using a high-throughput screening approach to identify compounds that promote differentiation [32].

Efforts to direct the differentiation of iPS cells to mature islet cells are also progressing but have not yet had the success of ESCs [33]. There are concerns about the epigenetic changes in these cells and this is undergoing intense investigation. For example, there are now genome-wide reference maps of DNA methylation and gene expression for 20 human ESC lines and 12 human iPS cell lines [34]. Such analyses make it possible to better understand the uniqueness of individual cell lines. Similar genome-wide mapping of epigenetic marks has been carried out in mouse ESCs [35]. Studies also indicate that microRNAs promise to play important roles for understanding iPS cells, as evidenced by the demonstration that knockdown of three microRNAs interfered with reprogramming efficiency [36].

There are many practical issues about preparing beta cells from individuals using iPS cell technology, but at some point it should be possible to produce these at a reasonable cost. One major advantage for such generated beta cells is that they would not be faced with allorejection. However, in the case of type 1 diabetes, these cells would be targets for autoimmunity and it would be necessary to develop strategies to resist this immune assault. For type 2 diabetes, these cells could be transplanted into a variety of locations without concern about immune rejection.

\section{Use of iPS cells to study disease pathogenesis}

iPS cells could also be an exciting way to study the pathogenesis of diabetes [7]. For example, for type 1 
diabetes it would be possible to learn more about autoimmunity by making iPS cells from affected individuals and by preparing differentiated cell types involved in pathogenesis; these cell types include thymus epithelial cells, dendritic cells, various types of $\mathrm{T}$ cells or even the target, the beta cell. For type 2 diabetes, it would be of considerable interest to study beta cells from subjects with the genetic associations found in GWAS [37]. Such beta cells could also be of great value to the pharmaceutical industry for testing new drugs.

\section{Beta cell regeneration in the adult pancreas}

There have been hopes that it might be possible to replace the beta cell deficit that occurs in diabetes by regenerating new beta cells from adult tissues. The pancreas has received the most attention, in particular regarding the potential for replication of pre-existing beta cells or neogenesis. The term neogenesis is usually used to refer to the formation of new islets in the pancreas from a precursor cell other than islet cells [38]. While there could be stem cells in the pancreas itself, observations to date point to the pancreatic duct epithelium as the most likely potential source for new islet formation.

\section{Beta cell replication}

Rodent beta cells have an impressive capacity for replication, as has been shown using genetic models of insulin resistance [39] and in various models of partial beta cell destruction [40]. The major factor driving this replication appears to be glucose, which through its metabolism in beta cells turns on signals for growth [41]. Importantly, this capacity declines with age [42]. The situation in humans is complex in that replication is active in neonatal life, allowing expansion of beta cell mass, but then drops markedly in childhood [43]. In most adult humans, the rate of beta cell replication as studied by markers such as Ki67 or other methods is either not measurable or very low [44-46]. Nonetheless, when islets are isolated from such individuals, a low rate of beta cell replication can be stimulated by high glucose and other agents [47]. Stimulation of replication is still considered to be an important therapeutic goal and progress is being made to understand the underlying cell cycle machinery [48].

\section{Generation of beta cells from pancreatic alpha cells}

Surprising results emerged after beta cells in mice were destroyed by genetically induced diphtheria toxin, in that some of the residual islet glucagon-secreting alpha cells appeared to assume a beta cell phenotype and were even able to restore glucose levels to normal. This occurred after many months [49]. However, it seems puzzling that there is little evidence that a similar process occurs when beta cells are killed by the toxin streptozocin; so many questions remain about the potential of this interesting phenomenon. It is of considerable interest that ectopic production of Pax4 in progenitor cells of mouse pancreas can lead to subsequent conversion of alpha cells to beta bells [50]. Further studies of pancreatic alpha cells will be needed to understand their potential as sources for replacement of beta cell functions.

\section{Neogenesis}

It has been hypothesized that the process of postnatal neogenesis is a recapitulation of islet development in fetal life, and that the pancreatic duct epithelium could be stimulated therapeutically to make new islets [38]. One approach would be to develop a medication that would stimulate the process of neogenesis within a patient's pancreas. Another approach would involve directed differentiation of duct cells into new islets in vitro that could then be transplanted [51,52]. There is still controversy about neogenesis, in part because of discrepant results from various mouse lineage-tracing models [53-58], but there is support for the concept that a population of duct cells could serve as multipotent progenitors capable of generating new exocrine and endocrine cells [53]. Two recent papers provide further support for the presence of postnatal neogenesis, the first showing it occurs in the neonatal period [59] and the second that it can occur after pancreatic injury [58]. In the latter paper, when both acinar and islet cells were mostly killed by diphtheria toxin produced under the control of the $P d x 1$ promoter, duct cells gave rise to both acinar and endocrine cells, with recovery of $60 \%$ of the beta cell mass and reversal of hyperglycemia. However, when only acinar cells were killed by elastase-driven toxin, duct cells only gave rise to new acinar cells. It is our view that in adult rodents, the most significant regeneration comes from beta cell replication, but that neogenesis from ducts does occur, most notably in the neonatal period, and can be stimulated following some forms of pancreatic injury. The human pancreas is more difficult to study but there are data suggesting that neogenesis can make an important contribution to beta cell turnover during adult life [38,60].

Studies using rodent models have shown that various agents (such as epidermal growth factor, gastrin and glucagon-like peptide 1 agonists), either alone or in combination, can stimulate neogenesis, and this has raised expectations that such an approach might be useful in humans [15]. Unfortunately, to date no evidence has emerged that these agents can increase beta cell mass in humans. However, it must be recognized that there is a need to develop better tools for measuring beta cell mass and that using insulin secretion to determine functional beta cell mass is only partially informative. 
The search for other stem/progenitor cells in the pancreas While much attention has been paid to duct cells as the potential origin of new islets, there has also been a search for other stem cells or precursor cells. It has been possible to clonally derive cells from pancreatic cells called pancreas-derived multipotent precursor cells that do not have ESC characteristics and can form neurosphere-like structures in vitro containing hundreds of cells [61]. The cells in these clusters, which can have either an islet cell or a neural phenotype, can be derived from dispersed cells from pancreas, but can also be developed from insulin-containing cells isolated using flow cytometry. This raises questions as to whether beta cells themselves have the potential to transdifferentiate into stem cells that are capable of regenerating even more beta cells. A different cell population has also been found in the pancreas of mice called very small embryonic-like stem cells [62]. Although these cells can differentiate to express some beta cell markers, their role in the pancreas and in other tissues remains to be defined.

\section{Adult non-pancreatic stem/precursor cells}

Due to the need for beta cell replacement therapy, much work has been done in the past decade to generate beta cells from a variety of cell sources. Some of the most notable efforts have been with cells derived from bone marrow and amniotic fluid that partially differentiate with manipulation in an in vitro environment $[63,64]$. Many experiments have also investigated whether various cells obtained from bone marrow turn into beta cells in the pancreas or in a transplant site using lineage tracing approaches, but these studies have been either unconvincing or negative $[65,66]$. A general approach has been to try to change the phenotype of various cell types in vitro by changing the environment and adding growth and differentiation factors. It has been possible to direct such cells to express some beta cell markers and even some insulin, but there have been no convincing reports that true beta cells have been formed.

Reprogramming differentiated cells derived from endoderm The reprogramming success of iPS cells has raised the possibility that cells derived from endoderm, such as those in liver or exocrine pancreas, could be more easily converted to beta cells than cells from other embryonic origins. The hope is that someday reprogramming of liver or exocrine pancreas could be accomplished using administered factors (for example, by a simple injection technique). Liver is an appealing target because portions of liver could be more easily removed than pancreatic tissue, and then reprogrammed in vitro, whereupon the islet cells could be generated and then transplanted.

Considerable effort has gone into reprogramming hepatocytes and biliary epithelial cells by introducing transcription factors such as Pdx1 and Ngn3 with viral vectors [67-69]. There has been success in generating cells with beta cell traits, including some insulin production, but there is uncertainty about how many of these cells can be produced, how similar they are to beta cells, and how useful they might be in reversing the diabetic state.

More encouraging progress has been made by reprogramming pancreatic exocrine cells using adenoviruses carrying the transcription factors Pdx1, Ngn3 and MafA [70]. These cells had many characteristics of pancreatic beta cells with regard to key transcription factors and insulin content, and they could partially reverse the diabetic state. Pdx1 is important for both early pancreatic and islet development. Ngn3 is essential for the specification of islet cells and MafA is needed for the final stages of beta cell maturation.

\section{Mesenchymal stromal cells and hematopoietic stem cells} Mesenchymal stromal cells (MSCs), also known as mesenchymal stem cells, have attracted a great deal of interest because of their potential to enhance regeneration of beta cells and/or modulate autoreactivity or alloreactivity $[6,71,72]$. Making progress in the area is difficult because MSCs have variable phenotypes and their actions and are not well understood. This is made even more complicated because many of these experiments have used bone-marrow-derived cells, which can include both hematopoietic stem cells (HSCs) and MSCs. There is still little evidence that either HSCs or MSCs can be converted into beta cells. However, recent data indicate that bone-marrow-derived cells can enhance beta cell regeneration through as yet ill-defined mechanisms [71]. Moreover, in the NOD mouse model of autoimmune diabetes, MSCs can be used to reverse the diabetic state [73]. Also potentially important, mobilized HSCs can prolong islet allograft survival in mice [74]. There have been a large number of clinical trials employing MSCs, mostly for cardiovascular diseases, but little evidence for efficacy has emerged.

However, in one study, subjects with new-onset type 1 diabetes were treated with autologous HSCs after conditioning with antithymocyte globulin and cyclophosphamide [75]. Preservation of beta cell function was impressive, but because of insufficient controls it is not possible to conclude that the efficacy had anything to do with the stem cells. It is also possible that the preservation of insulin secretion was entirely due to the strong (and, in our opinion, dangerous) level of immunosuppression that was employed.

\section{Other stem-cell-based approaches}

The focus of this review has been beta cell replacement, but advances in stem cell research might eventually 
provide support for alternative approaches for treatment. It is possible that stem cell biology might be used to manipulate the immune system such that the loss of tolerance in type 1 diabetes can be restored. Perhaps it will be possible one day to direct adipocyte stem cells to make more energy-consuming brown fat, which could be useful for weight control [76]. Other strategies might lead to reduction of visceral adiposity, which contributes to insulin resistance and vascular disease. Another possibility is that stem cells might also one day be used to regenerate kidney or retinal cells in diabetic patients, or to slow hyperglycemia-induced microvascular disease.

\section{Stem cell tourism}

In spite of the impressive promise of stem cells, no proven benefits have been demonstrated for the treatment of diabetes. Yet many people with diabetes have received stem cell treatments that have not been fully investigated, exposing these individuals to unnecessary expense and potential harm. A quick search of the internet shows many websites that extol the benefits of stem cells for diabetes and many other diseases. There are a number of clinical trials underway that are described on the website Clinicaltrials.gov [77]. Some of these are well designed, will test important hypotheses and have good safety provisions. However, other trials listed on the website may not employ rigorous science and may not be safe. Various responsible organizations are providing advice to people in search of stem cell treatments. In particular, the International Society for Stem Cell Research devotes part of its website to provide information and guidelines to help assess purported treatments and clinical trials [78].

\section{Conclusion and future perspectives}

There have been extraordinary recent advances in our understanding of diabetes because of its priority as a major health problem and the remarkable development of scientific methods in genomics, genetics, cell biology and other fields. In this review, we have described some of these advances and have focused upon ways in which stem cell research might lead the way to new therapies and paths to better understand the pathophysiology of the various forms of diabetes. There has been particular emphasis upon how stem cells might allow replenishment of the beta cell deficit that is such a fundamental part of diabetes, but there are also various ways in which stem cell research might help with the problems of autoimmunity, insulin resistance and the vascular complications of diabetes. Progress with stem cell biology has been impressive and prospects for the future are very exciting.

\section{Abbreviations}

Arx, aristaless-related homeobox; ChiP-seq, chromatin immunoprecipitation and parallel sequencing; CTLA4, cytotoxic T-lymphocyte-associated protein 4;
ESC, embryonic stem cell; Foxa2, forkhead box A2; GWAS, genome-wide association studies; HLA, human leukocyte antigen; Hnf1b, hepatocyte nuclear factor 1 homeobox B; Hnf6, one cut homeobox 1; HSC, hematopoietic stem cell; INS VNTR, insulin variable number of tandem repeats; IL2A, interleukin 2 receptor alpha; iPS cell, induced pluripotent stem cell; MafA, Maf transcription factor A; MafB, Maf transcription factor B; MODY, maturity-onset diabetes of the young; MSC, mesenchymal stromal cell; Ngn3, neurogenin 3; Pax6, paired box 6; Pdx1, pancreatic duodenal homeobox; PTPN22, protein tyrosine phosphatase-22; RXF family, regulatory factor X-box binding family; Sox9, SRYbox containing gene 9

\section{Competing interests}

The authors declare that they have no competing interests.

\section{Acknowledgments}

Supported by: NIH RC4 DK090781-01 (GCW), R01 DK 66056 (SBW) and P30 DK36836 Joslin Diabetes and Endocrinology Research Center (DERC); Juvenile Diabetes Research Foundation 2008-522 and 2007-1063 (GCW) and 2008-641 (SBW); the Swiss National Foundation (CCW) and the Diabetes Research and Wellness Foundation (GCW). All of the authors contributed to writing the manuscript.

Published: 27 September 2011

\section{References}

1. Gruessner AC, Sutherland DE: Pancreas transplant outcomes for United States (US) and non-US cases as reported to the United Network for Organ Sharing (UNOS) and the International Pancreas Transplant Registry (IPTR) as of June 2004. Clin Transplant 2005, 19:433-455.

2. Alejandro R, Barton FB, Hering BJ, Wease S, Collaborative Islet Transplant Registry I: 2008 Update from the Collaborative Islet Transplant Registry. Transplantation 2008, 86:1783-1788.

3. Butler AE, Janson J, Bonner-Weir S, Ritzel R, Rizza RA, Butler PC: Beta-cell deficit and increased beta-cell apoptosis in humans with type 2 diabetes. Diabetes 2003, 52:102-110.

4. Nath DS, Gruessner AC, Kandaswamy R, Gruessner RW, Sutherland DE, Humar A: Outcomes of pancreas transplants for patients with type 2 diabetes mellitus. Clin Transplant 2005, 19:792-797.

5. Diabetes Control and Complications Trial/Epidemiology of Diabetes Interventions and Complications (DCCT/EDIC) Research Group, Nathan DM, Zinman B, Cleary PA, Backlund JY, Genuth S, Miller R, Orchard TJ: Modern-day clinical course of type 1 diabetes mellitus after 30 years' duration: the diabetes control and complications trial/epidemiology of diabetes interventions and complications and Pittsburgh epidemiology of diabetes complications experience (1983-2005). Arch Intern Med 2009, 169:1307-1316.

6. Abdi R, Fiorina P, Adra CN, Atkinson M, Sayegh MH: Immunomodulation by mesenchymal stem cells: a potential therapeutic strategy for type 1 diabetes. Diabetes 2008, 57:1759-1767.

7. Maehr R, Chen S, Snitow M, Ludwig T, Yagasaki L, Goland R, Leibel RL, Melton DA: Generation of pluripotent stem cells from patients with type 1 diabetes. Proc Natl Acad Sci U S A 2009, 106:15768-15773.

8. Bluestone JA, Herold K, Eisenbarth G: Genetics, pathogenesis and clinical interventions in type 1 diabetes. Nature 2010, 464:1293-1300.

9. Nakayama M, Abiru N, Moriyama H, Babaya N, Liu E, Miao D, Yu L, Wegmann DR, Hutton JC, Elliott JF, Eisenbarth GS: Prime role for an insulin epitope in the development of type 1 diabetes in NOD mice. Nature 2005, 435:220-223

10. Hakonarson H, Grant SF: GWAS and its impact on elucidating the etiology of diabetes. Diabetes Metab Res Rev 2011. doi: 10.1002/dmrr.1221.

11. Weir GC, Marselli L, Marchetti $P$, Katsuta H, Jung MH, Bonner-Weir S: Towards better understanding of the contributions of overwork and glucotoxicity to the beta-cell inadequacy of type 2 diabetes. Diabetes Obes Metab 2009, 11(Suppl 4):82-90.

12. Meigs JB, Shrader P, Sullivan LM, McAteer JB, Fox CS, Dupuis J, Manning AK, Florez JC, Wilson PW, D'Agostino RB Sr, Cupples LA: Genotype score in addition to common risk factors for prediction of type 2 diabetes. $N$ Engl $J$ Med 2008, 359:2208-2219

13. Rubio-Cabezas O, Klupa T, Malecki MT; CEED3 Consortium: Permanent neonatal diabetes mellitus - the importance of diabetes differential diagnosis in neonates and infants. Eur J Clin Invest 2011, 41:323-333. 
14. Glaser B: Genetic analysis of complex disease - a roadmap to understanding or a colossal waste of money. Pediatr Endocrinol Rev 2010, 7:258-265.

15. Halban PA, German MS, Kahn SE, Weir GC: Current status of islet cell replacement and regeneration therapy. J Clin Endocrinol Metab 2010, 95:1034-1043.

16. Pan FC, Wright C: Pancreas organogenesis: from bud to plexus to gland. Dev Dyn 2011, 240:530-565

17. Jonsson J, Carlsson L, Edlund T, Edlund H: Insulin-promoter-factor 1 is required for pancreas development in mice. Nature 1994, 371:606-609.

18. Oliver-Krasinski JM, Kasner MT, Yang J, Crutchlow MF, Rustgi AK, Kaestner KH, Stoffers DA: The diabetes gene $\mathrm{Pdx} 1$ regulates the transcriptional network of pancreatic endocrine progenitor cells in mice. J Clin Invest 2009, 119:1888-1898.

19. Smith SB, Qu HQ, Taleb N, Kishimoto NY, Scheel DW, Lu Y, Patch AM, Grabs R Wang J, Lynn FC, Miyatsuka T, Mitchell J, Seerke R, Désir J, Eijnden SV, Abramowicz M, Kacet N, Weill J, Renard ME, Gentile M, Hansen I, Dewar K, Hattersley AT, Wang R, Wilson ME, Johnson JD, Polychronakos C, German MS: Rfx6 directs islet formation and insulin production in mice and humans. Nature 2010, 463:775-780.

20. Nishimura W, Kondo T, Salameh T, El Khattabi I, Dodge R, Bonner-Weir S, Sharma A: A switch from MafB to MafA expression accompanies differentiation to pancreatic beta-cells. Dev Biol 2006, 293:526-539.

21. Mutskov V, Felsenfeld $\mathrm{G}$ : The human insulin gene is part of a large open chromatin domain specific for human islets. Proc Natl Acad Sci U S A 2009, 106:17419-17424.

22. Dhawan S, Georgia S, Tschen SI, Fan G, Bhushan A: Pancreatic beta cell identity is maintained by DNA methylation-mediated repression of Arx. Dev Cell 2011, 20:419-429.

23. Bhandare R, Schug J, Le Lay J, Fox A, Smirnova O, Liu C, Naji A, Kaestner KH: Genome-wide analysis of histone modifications in human pancreatic islets. Genome Res 2010, 20:428-433.

24. Fernandez-Valverde SL, Taft RJ, Mattick JS: MicroRNAs in beta-cell biology, insulin resistance, diabetes and its complications. Diabetes 2011, 60:1825-1831.

25. Poy MN, Hausser J, Trajkovski M, Braun M, Collins S, Rorsman P, Zavolan M, Stoffel M: miR-375 maintains normal pancreatic alpha- and beta-cell mass. Proc Natl Acad SciU S A 2009, 106:5813-5818.

26. Melkman-Zehavi T, Oren R, Kredo-Russo S, Shapira T, Mandelbaum AD, Rivkin $\mathrm{N}$, Nir T, Lennox KA, Behlke MA, Dor Y, Hornstein E: miRNAs control insulin content in pancreatic beta-cells via downregulation of transcriptional repressors. EMBO J 2011, 30:835-845.

27. Weir GC, Bonner-Weir S: Five stages of evolving beta-cell dysfunction during progression to diabetes. Diabetes 2004, 53(Suppl 3):S16-21.

28. Scharp DW, Lacy PE, Santiago JV, McCullough CS, Weide LG, Bayle PJ, Falqui L, Marchetti P, Ricordi C, Gingerich RL: Results of our first nine intra portal islet allografts in type 1, insulin dependent diabetic patients. Transplantation 1991, 51:76-85.

29. King AJ, Fernandes JR, Hollister-Lock J, Nienaber CE, Bonner-Weir S, Weir GC: Normal relationship of beta- and non-beta-cells not needed for successful islet transplantation. Diabetes 2007, 56:2312-2318.

30. Kroon E, Martinson LA, Kadoya K, Bang AG, Kelly OG, Eliazer S, Young H, Richardson M, Smart NG, Cunningham J, Agulnick AD, D'Amour KA, Carpenter MK, Baetge EE: Pancreatic endoderm derived from human embryonic stem cells generates glucose-responsive insulin-secreting cells in vivo. Nat Biotechnol 2008, 26:443-452.

31. Lee SH, Hao E, Savinov AY, Geron I, Strongin AY, Itkin-Ansari P: Human betacell precursors mature into functional insulin-producing cells in an immunoisolation device: implications for diabetes cell therapies. Transplantation 2009, 87:983-991.

32. Borowiak M, Maehr R, Chen S, Chen AE, Tang W, Fox JL, Schreiber SL, Melton DA: Small molecules efficiently direct endodermal differentiation of mouse and human embryonic stem cells. Cell Stem Cell 2009, 4:348-358.

33. Alipio Z, Liao W, Roemer EJ, Waner M, Fink LM, Ward DC, Ma Y: Reversal of hyperglycemia in diabetic mouse models using induced-pluripotent stem (iPS)-derived pancreatic beta-like cells. Proc Natl Acad Sci U S A 2010, 107:13426-13431

34. Bock C, Kiskinis E, Verstappen G, Gu H, Boulting G, Smith ZD, Ziller M, Croft GF, Amoroso MW, Oakley DH, Gnirke A, Eggan K, Meissner A: Reference Maps of human ES and iPS cell variation enable high-throughput characterization of pluripotent cell lines. Cell 2011, 144:439-452.
35. Pastor WA, Pape UJ, Huang Y, Henderson HR, Lister R, Ko M, McLoughlin EM, Brudno Y, Mahapatra S, Kapranov P, Tahiliani M, Daley GQ, Liu XS, Ecker JR, Milos PM, Agarwal S, Rao A: Genome-wide mapping of 5-hydroxymethylcytosine in embryonic stem cells. Nature 2011 473:394-397.

36. Li Z, Yang CS, Nakashima K, Rana TM: Small RNA-mediated regulation of iPS cell generation. EMBO J 2011, 30:823-834.

37. Billings LK, Florez JC: The genetics of type 2 diabetes: what have we learned from GWAS? Ann N Y Acad Sci 2010, 1212:59-77.

38. Bonner-Weir S, Li WC, Ouziel-Yahalom L, Guo L, Weir GC, Sharma A: Beta-cell growth and regeneration: replication is only part of the story. Diabetes 2010, 59:2340-2348,

39. Bruning JC, Winnay J, Bonner-Weir S, Taylor SI, Accili D, Kahn CR: Development of a novel polygenic model of NIDDM in mice heterozygous for IR and IRS-1 null alleles. Cell 1999, 88:561-572

40. Nir T, Melton DA, Dor Y: Recovery from diabetes in mice by beta cell regeneration. J Clin Invest 2007, 117:2553-2561.

41. Porat S, Weinberg-Corem N, Tornovsky-Babaey S, Schyr-Ben-Haroush R, Hija A, Stolovich-Rain M, Dadon D, Granot Z, Ben-Hur V, White P, Girard CA, Karni R, Kaestner KH, Ashcroft FM, Magnuson MA, Saada A, Grimsby J, Glaser B, Dor Y: Control of pancreatic beta cell regeneration by glucose metabolism. Cell Metab 2011, 13:440-449.

42. Rankin MM, Kushner JA: Adaptive beta-cell proliferation is severely restricted with advanced age. Diabetes 2009, 58:1365-1372.

43. Meier JJ, Butler AE, Saisho Y, Monchamp T, Galasso R, Bhushan A, Rizza RA, Butler PC: Beta-cell replication is the primary mechanism subserving the postnatal expansion of beta-cell mass in humans. Diabetes 2008 , 57:1584-1594

44. In't Veld P, De Munck N, Van Belle K, Buelens N, Ling Z, Weets I, Haentjens P, Pipeleers-Marichal M, Gorus F, Pipeleers D: Beta-cell replication is increased in donor organs from young patients after prolonged life support. Diabetes 2010, 59:1702-1708.

45. Perl S, Kushner JA, Buchholz BA, Meeker AK, Stein GM, Hsieh M, Kirby M, Pechhold S, Liu EH, Harlan DM, Tisdale JF: Significant human beta-cell turnover is limited to the first three decades of life as determined by in vivo thymidine analog incorporation and radiocarbon dating. J Clin Endocrinol Metab 2010, 95:E234-239.

46. Reers C, Erbel S, Esposito I, Schmied B, Buchler MW, Nawroth PP, Ritzel RA: Impaired islet turnover in human donor pancreata with aging. Eur Endocrino/ 2009, 160:185-191.

47. Nielsen $\mathrm{JH}$ : Growth and function of the pancreatic b cell in vitro: effects of glucose, hormones and serum factors on mouse, rat and human pancreatic iselts in organ culture. Acta Endocrinol(Kbh) 1985, 108(Suppl 266):1.

48. Fiaschi-Taesch N, Bigatel TA, Sicari B, Takane KK, Salim F, Velazquez-Garcia S, Harb G, Selk K, Cozar-Castellano I, Stewart AF: Survey of the human pancreatic beta-cell G1/S proteome reveals a potential therapeutic role for cdk- 6 and cyclin D1 in enhancing human beta-cell replication and function in vivo. Diabetes 2009, 58:882-893.

49. Thorel F, Nepote V, Avril I, Kohno K, Desgraz R, Chera S, Herrera PL: Conversion of adult pancreatic alpha-cells to beta-cells after extreme beta-cell loss. Nature 2010, 464:1149-1154.

50. Collombat P, Xu X, Ravassard P, Sosa-Pineda B, Dussaud S, Billestrup N, Madsen OD, Serup P, Heimberg H, Mansouri A: The ectopic expression of Pax4 in the mouse pancreas converts progenitor cells into alpha and subsequently beta cells. Cell 2009, 138:449-462.

51. Bonner-Weir S, Taneja M, Weir GC, Tatarkiewicz K, Song KH, Sharma A, O'Neil $\mathrm{JJ}$ : In vitro cultivation of human islets from expanded ductal tissue. Proc Natl Acad Sci U S A 2000, 97:7999-8004.

52. Yatoh S, Dodge R, Akashi T, Omer A, Sharma A, Weir GC, Bonner-Weir S: Differentiation of affinity-purified human pancreatic duct cells to betacells. Diabetes 2007, 56:1802-1809.

53. Inada A, Nienaber C, Katsuta H, Fujitani Y, Levine J, Morita R, Sharma A, Bonner-Weir S: Carbonic anhydrase II-positive pancreatic cells are progenitors for both endocrine and exocrine pancreas after birth. Proc Natl Acad SciU SA 2008, 105:19915-19919.

54. Kopp JL, Dubois CL, Schaffer AE, Hao E, Shih HP, Seymour PA, Ma J, Sander M: Sox9+ ductal cells are multipotent progenitors throughout development but do not produce new endocrine cells in the normal or injured adult pancreas. Development 2011, 138:653-665.

55. Furuyama K, Kawaguchi Y, Akiyama H, Horiguchi M, Kodama S, Kuhara T, 
Hosokawa S, Elbahrawy A, Soeda T, Koizumi M, Masui T, Kawaguchi M, Takaori K, Doi R, Nishi E, Kakinoki R, Deng JM, Behringer RR, Nakamura T, Uemoto S: Continuous cell supply from a Sox9-expressing progenitor zone in adult liver, exocrine pancreas and intestine. Nat Genet 2011, 43:34-41.

56. Xu X, D'Hoker J, Stange G, Bonne S, De Leu N, Xiao X, Van de Casteele M, Mellitzer G, Ling Z, Pipeleers D, Bouwens L, Scharfmann R, Gradwohl G, Heimberg H: Beta cells can be generated from endogenous progenitors in injured adult mouse pancreas. Cell 2008, 132:197-207.

57. Solar M, Cardalda C, Houbracken I, Martin M, Maestro MA, De Medts N, Xu X, Grau V, Heimberg H, Bouwens L, Ferrer J: Pancreatic exocrine duct cells give rise to insulin-producing beta cells during embryogenesis but not after birth. Dev Cell 2009, 17:849-860.

58. Criscimanna A, Speicher JA, Houshmand G, Shiota C, Prasadan K, Ji B, Logsdon CD, Gittes GK, Esni F: Duct cells contribute to regeneration of endocrine and acinar cells following pancreatic damage in adult mice. Gastroenterology, in press.

59. Nakamura K, Minami K, Tamura K, lemoto K, Miki T, Seino S: Pancreatic betacells are generated by neogenesis from non-beta-cells after birth. Biomed Res 2011,32:167-174

60. Butler AE, Cao-Minh L, Galasso R, Rizza RA, Corradin A, Cobelli C, Butler PC Adaptive changes in pancreatic beta cell fractional area and beta cell turnover in human pregnancy. Diabetologia 2010, 53:2167-2176.

61. Smukler SR, Arntfield ME, Razavi R, Bikopoulos G, Karpowicz P, Seaberg R, Dai F, Lee S, Ahrens R, Fraser PE, Wheeler MB, van der Kooy D: The adult mouse and human pancreas contain rare multipotent stem cells that express insulin. Cell Stem Cell 2011, 8:281-293.

62. Ratajczak MZ, Liu R, Ratajczak J, Kucia M, Shin DM: The role of pluripotent embryonic-like stem cells residing in adult tissues in regeneration and longevity. Differentiation 2011, 81:153-161.

63. Jiang $Y$, Jahagirdar BN, Reinhardt RL, Schwartz RE, Keene CD, Ortiz-Gonzalez XR, Reyes M, LenvikT, Lund T, Blackstad M, Du J, Aldrich S, Lisberg A, Low WC, Largaespada DA, Verfaillie CM: Pluripotency of mesenchymal stem cells derived from adult marrow. Nature 2002, 418:41-49.

64. De Coppi P, Bartsch G, Jr., Siddiqui MM, Xu T, Santos CC, Perin L, Mostoslavsky G, Serre AC, Snyder EY, Yoo JJ, Furth ME, Soker S, Atala A: Isolation of amniotic stem cell lines with potential for therapy. Nat Biotechno/ 2007, 25:100-106.

65. Akashi T, Shigematsu H, Hamamoto Y, Iwasaki H, Yatoh S, Bonner-Weir S Akashi K, Weir GC: Bone marrow or foetal liver cells fail to induce islet regeneration in diabetic Akita mice. Diabetes Metab Res Rev 2008, 24:585-590.

66. Hamamoto Y, Akashi T, Inada A, Bonner-Weir S, Weir GC: Lack of evidence for recipient precursor cells replenishing beta-cells in transplanted islets. Cell Transplant 2010, 19:1563-1572.
67. Yechoor V, Liu V, Paul A, Lee J, Buras E, Ozer K, Samson S, Chan L: Gene therapy with neurogenin 3 and betacellulin reverses major metabolic problems in insulin-deficient diabetic mice. Endocrinology 2009, 150:4863-4873.

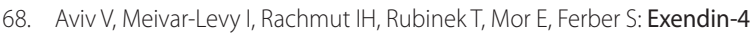
promotes liver cell proliferation and enhances the PDX-1-induced liver to pancreas transdifferentiation process. J Bio/ Chem 2009, 284:33509-33520.

69. Nagaya M, Katsuta H, Kaneto H, Bonner-Weir S, Weir GC: Adult mouse intrahepatic biliary epithelial cells induced in vitro to become insulinproducing cells. J Endocrinol 2009, 201:37-47.

70. Zhou Q, Brown J, Kanarek A, Rajagopal J, Melton DA: In vivo reprogramming of adult pancreatic exocrine cells to beta-cells. Nature 2008, 455:627-632.

71. Hess D, Li L, Martin M, Sakano S, Hill D, Strutt B, Thyssen S, Gray DA, Bhatia M: Bone marrow-derived stem cells initiate pancreatic regeneration. Nat Biotechnol 2003, 21:763-770.

72. Lee RH, Seo MJ, Reger RL, Spees JL, Pulin AA, Olson SD, Prockop DJ: Multipotent stromal cells from human marrow home to and promote repair of pancreatic islets and renal glomeruli in diabetic NOD/scid mice. Proc Natl Acad Sci U S A 2006, 103:17438-17443.

73. Jurewicz M, Yang S, Augello A, Godwin JG, Moore RF, Azzi J, Fiorina P, Atkinson M, Sayegh MH, Abdi R: Congenic mesenchymal stem cell therapy reverses hyperglycemia in experimental type 1 diabetes. Diabetes 2010, 59:3139-3147.

74. Fiorina P, Jurewicz M, Vergani A, Petrelli A, Carvello M, D'Addio F, Godwin JG, Law K, Wu E, Tian Z, Thoma G, Kovarik J, La Rosa S, Capella C, Rodig S, Zerwes HG, Sayegh MH, Abdi R: Targeting the CXCR4-CXCL12 axis mobilizes autologous hematopoietic stem cells and prolongs islet allograft survival via programmed death ligand 1. J Immuno/ 2011, 186:121-131.

75. Couri CE, Oliveira MC, Stracieri AB, Moraes DA, Pieroni F, Barros GM, Madeira MI, Malmegrim KC, Foss-Freitas MC, Simões BP, Martinez EZ, Foss MC, Burt RK, Voltarelli JC: C-peptide levels and insulin independence following autologous nonmyeloablative hematopoietic stem cell transplantation in newly diagnosed type 1 diabetes mellitus. JAMA 2009, 301:1573-1579.

76. Tseng YH, Cypess AM, Kahn CR: Cellular bioenergetics as a target for obesity therapy. Nat Rev Drug Discov 2010, 9:465-482.

77. ClinicalTrials.gov [http://clinicaltrials.gov/]

78. ISSCR (International Society for Stem Cell Research) [http://www.isscr.org/]

doi:10.1186/gm277

Cite this article as: Weir GC, et al:: Stem cell approaches for diabetes:

towards beta cell replacement. Genome Medicine 2011, 3:61. 